\title{
最近の畨学
}

\section{5. 第二口外}

血管の蛋白透過性の定量法

$$
\text { 第二口外 中島 民 雄 }
$$

炎症の最も著名な変化である血管の蛋白透過性の克進 を測定する方法は，今日まで数多くのものが開発されて いる。比較的良く用いられる方法はラットの足に炎症反 応を起し, そこにあらわれる浮腫を, 水分, 容積, 重量 などの増加を定量して測定するもの，直径 200 300 ̊ の炭素粒子の静注により, 炎症部位の血管のみをラベル し，透明標本として観察するものなどであるが，血管の 蛋白透過性という意味では定量性に欠けている。

最も定量的な方法としては I ${ }^{131}$ をラベルした蛋白を 静注して, 炎症部位の 渗出液またはリンパ液の radioactivity を測る方法があるが，応用範囲が狭いたためま り用いられていない。

現在広く用いられている方法は, Menkin(1936) によ り開発された, 炎症部位への色素の集積をみる方法であ る。Evans blue Trypan blue, Pontamine blue などの 色素を静注するとただちに，血中の蛋白，とくにアルブ ミンと結合して dye-protein complex をつくり, 血管の 透過性が允進している部位では色素の集積がおこる。こ の方法は，はじめ定性的な方法であつたが，Miles(1952) らによつて色素の集積部位の平均直径が Histamine, Leukotaxin などの濃度の対数に比例して変化すること が発見されて以来, その平均直径をもつて反応の強さを あらわすようになつた。しかし，この判定方法は完全に 定量的でないため最近になつて集積した色素をその局所 から抽出，定量しようとする試みがなされている。 Judah(1962)らは皮膚組織を細かくしたのち, リピドを 除きピリジン水溶液で色素を抽出し，Carr(1964）らは 尿素溶液中で皮膚をホモジナイズし，アセトンおよび Somogyi reagents で蛋白と色素を分離し, 蛋白を沈搌, 濾過により色素を抽出している。これらの方法の要点は 皮膚をできるだけ細かくすることにあるようで，そのた めに Judah らはドライアイスとメタノールで皮膚を凍 結させ特別に作つた percussion mortor で粉砕してい る。また, 新田(1963) らはエタノールとジオキサンで皮 膚を処理したのち, 八サミで細切している。しかし，こ れらの方法は組織を十分細かくできず，色素の抽出には かなりの時間を要するようである。そこで筆者(1967) は 表のような方法で色素の抽出をおこなつてみた。 $5 \sim 40$ $\mu \mathrm{g}$ の Pontamine blue を注射した皮虐をハサミで細切 し, $85^{\circ} \mathrm{C}$ の湯浴中で, $7.0 \mathrm{ml}$ の $10 \%$ のリクロール 酢酸エタノール溶液で 10 分間処理して, 組織蛋白を変

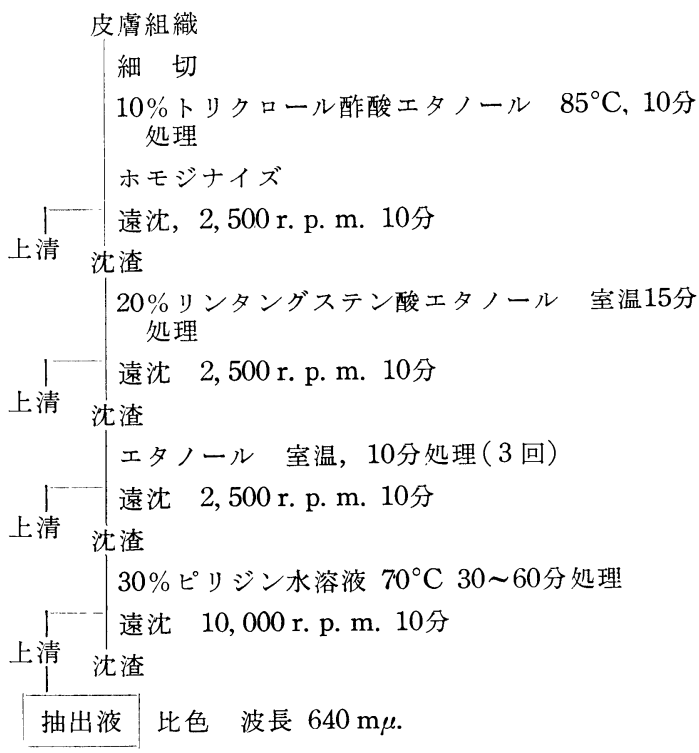

性させてからホモジナイズした。これを 2,500 r. p. m・ で 10 分間遠沈し，上清を除去した。次に $10 \mathrm{ml}$ の $20 \%$ リンタングステン酸エタノール溶液で室温で 15 分間処 理して，ゲラチン化したコラゲンを不溶性にし，同様に 遠沈し，上清を除去した。その後，リピドを除くため 10 $\mathrm{ml}$ のエタノールで室温で 10 分間処理して遠沈し, 上 清をすて，さらにこの操作を二回くり返した。最後に $70^{\circ} \mathrm{C}$ 湯浴中で, $3.5 \mathrm{ml}$ の $30 \%$ ピリジン水溶液で 30 分 ６0 分かけて色素を抽出した。これを 10,000 r. p. m. で 10 分間遠沈し得られた上清を波長 $640 \mathrm{~m} \mu$ で比色し, 色素量を求めた。色素の回収率は 90 94\%で非常に良 好であつた。

1927 年に Sir Thomas Lewis が Histamine 炎症 反応の mediator として注目して以来, Leukotaxin, Bradykinin, Kallikrein など, 多くの Mediator が発 見され，炎症反応がその際に遊離ないし活性化される endogenous subtance に起因することが明らかになつ たが，今日では上記のような色素抽出による血管の蛋白 透過性の定量はこのような炎症反応の生化学的な機序の 研究には欠かせない方法となつている。 